A BOWL FOR A COIN 



\section{A BOWL FOR A COIN A}

A Commodity History of Japanese Tea

\section{William WAyne FARRIS}

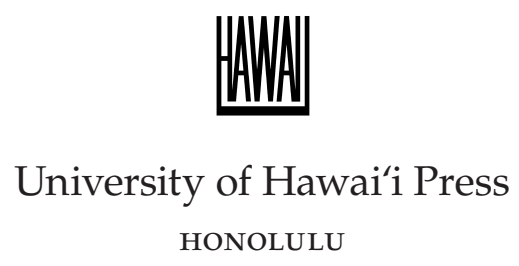


(C) 2019 University of Hawai`i Press

\section{Library of Congress Cataloging-in-Publication Data}

Names: Farris, William Wayne, author.

Title: A bowl for a coin: a commodity history of Japanese tea / William Wayne Farris.

Description: Honolulu: University of Hawai``i Press, [2019] | Includes bibliographical references and index.

Identifiers: LCCN 2018040370 | ISBN 9780824876609 (cloth alk. paper) Amazon Kindle 9780824878528 EPUB 9780824882624 PDF 9780824882617

Subjects: LCSH: Tea—Japan—History. | Tea trade—Japan—History.

Classification: LCC HD9198.J32 F37 2019 | DDC 338.1/73720952-dc23

LC record available at https://lccn.loc.gov/2017025008

Cover art: Tea peddlers around 1400. Source: "A Bowl for a Coin (ippuku issen)," Shichijüichi ban shokunin utaawase emaki (artist unknown). TNM Image Archives.

An electronic version of this book is freely available, thanks to the support of libraries working with Knowledge Unlatched. KU is a collaborative initiative designed to make high-quality books open access for the public good. The open-access ISBNs for this book are 9780824882617 (PDF) and 9780824882624 (EPUB). More information about the initiative and links to the open-access version can be found at www.knowledgeunlatched.org.

(c) (1) $\Theta \Theta$

The open access version of this book is licensed under Creative Commons Attribution-NonCommercial-NoDerivatives 4.0 International (CC and shared for non-commercial purposes, provided credit is given to the author. Derivative works and commercial uses require permission from the publisher. For details, see https://creativecommons.org/licenses/by-nc-nd/4.0/. 
To my beloved brother Al, his wife Sarah, and their family 
